Maryna Baldzhy, Professor, Odessa National Economic University (Odessa, Ukraine) ${ }^{1}$

\title{
ASSESSMENT OF RISKS UNDER BALANCED NATURE USE IN RECREATIONAL-DEVELOPED TERRITORIES
}

\begin{abstract}
On the basis of theoretical and methodological research in risk and environmental management, risk assessment is proposed in the balanced use of natural resources through the use of a universal approach that will enable to identify the overall effects of environmental impact and identify possible ways of making decisions, taking into the account all the consequences and probabilities of their occurrence.
\end{abstract}

Keywords: sustainable use of natural resources, risk, uncertainty, assessment, recreational-developed areas, integral indicator.

\section{Introduction}

The intensification of economic activity in the field of natural resources leads to a destructive force and a necessity for radical research from the scientists who study the balanced use of nature, because the uncertainty and high degree of risk at implementation of these consequences of management are left out of consideration. In conditions of implementation of balanced nature management projects, the problem of analysis and risk assessment becomes of particular importance, which is related to the irreversibility of events with the use of natural resources.

The issue of risk research is widely knwon in the scientific literature. Monographic works by P. Bernstein, V. Granaturov, S. Ilyashenko, S. Klymenko, O. Dubrov contain theoretical and methodological proposals on the conceptual approaches to the development of risk-taking and applied researches for assessing the risks of socio-ecological and economic orientation. Along with this, there are left uncertain different approaches to complex risk assessment of the innovative approach of nature use, namely - balanced, based on the principles of sustainability, and actively implemented in economic activities.

\section{Setting the task and its solution}

The main objective of the study has been selected the development of a universal approach to risk assessment with balanced environmental use, which will enable to identify the overall effects of the environmental impact and identify possible ways of decision making, taking into account all the consequences of management.

1 Affiliated to University of Economics and Humanities (Bielsko-Biała, Poland) 
To solve this goal, the following tasks are outlined:

- to study the main provisions of risk, its possible manifestations in the use of nature;

- to substantiate the system of risks, according to the criterion of uncertainty in the nature management;

- to determine the criteria basis for conducting an assessment of the risks of nature use in recreational-developed territories;

- to formulate provisions of the integrated assessment of the risks of balanced use of nature;

- to substantiate the conduct of the ranking of recreational-developed territories on the basis of a comprehensive assessment of the risks of sustainable use of nature.

\section{Materials and methods}

The research methods used are the methods of probability theory and risk, namely: the objective method, which allowed to determine the probability of separating the interval of frequency, through what happens to certain events; subjective method, which makes it necessary to conduct expert assessments, that is, the use of indicators of subjective probability. The source materials for the elaboration of the above proposals were the statistical data of the recreational-developed territories.

\section{Main part}

2.1. The theory of Modern risk is considering risk not only as an undesirable sign of uncertainty about future events, but also as a source of positive, lucrative opportunities, that separates two types of risks: risk-negative and risk-positive. The first must be avoided, and the second one must be balanced, because it is the bearer of a potential positive result. Sometimes the risk is considered as a three-dimensional model: risk - as a threat, risk - as uncertainty and risk as a chance. In the first two cases, it needs to be minimized, and the last one - optimization [Бернстайн, 2000, 209]. In environmental use, the risk may be in all of the listed conditions. Risk - is an objectively inevitable element of the adoption of any management decision, because uncertainty is an inevitable characteristic of the conditions of management. It only takes place where there can be at least two or more possible alternative outcomes. Most management decisions are made under uncertainty and economic risk. In the conditions of objective existence of risk, there is a need for a certain mechanism, which allows taking into account the last when making and implementing business decisions. Such a mechanism is called risk management [Прокопенко, и др., 2017, 289]. 
Considering the risk as a category, it is expedient to emphasize its economic, social and environmental nature, which can both individually and complexly influence the results of environmental management, in which assessment can be carried out quantitatively or qualitatively. In the scientific literature sufficiently widely interpreted the interpretation of these definitions [Бернстайн, 2000; Гранатуров, 1999; Ілляшенко, 2004; Клименко, Дуброва, 2004; Балджи, 2013 и др.], Therefore we consider it inappropriate to dwell on this issue and in subsequent considerations, based on existing developments.

Questions of the balanced use of nature are widely considered by domestic scientists, in particular, T. I. Tunitsa. Balanced nature is seen as a three-way process for the use, protection and reproduction of natural resources, ensuring a balance between the processes of use, reproduction and protection of the last [Туниця, 2006, 26].

2.2. We are proposing the creation of a universal approach to risk assessment in a balanced use of natural resources, which will enable us to identify the overall effects of the environmental impact.

The risk is closely related to the uncertainty - with the increase in the degree of the latest patterns of manifestation of transformational events and environmental and social costs, the lack of reliability of the characteristics and risk assessment is increased, and, consequently, the justification of the decisions is reduced.

The risk system, according to the criteria of uncertainty in the nature management, can be presented as the following:

$$
\begin{aligned}
& R_{r} \leq R_{p} \leq R_{e} \\
& R_{r}<R_{m} \\
& R_{e}<R_{\text {max }}
\end{aligned}
$$

where $R_{r}$ - risk of occurrence of the event (consequences);

$R_{p}$ - possible risk;

$R_{e}$ - admissible risk;

$R_{m}$ - average risk level;

$R_{\max }-$ maximum risk.

Quantitative estimation of uncertainty $(N)$ can be performed by definition of entropy:

$$
N=\sum_{i=1}^{n} P_{i} \log P_{i}
$$

where $P_{i}$ - probability of occurrence of events. 
A generalized risk assessment based on the mathematical expectation of a particular event (or consequences) and degree of uncertainty, has the form:

$$
R=N\left(\sum_{i=1}^{j}\left|P_{i j} X_{i}\right|\right)
$$

where $X_{i}-$ is the size of the damage.

To verify economic activities in the field of natural resources, a risk factor is calculated, which characterizes the ratio of the maximum possible damage to the available resources and determines the degree of the relationship between income and risk, using the risk-return ratio. When determining the risk factor, the optimal ratio is considered to be of $30 \%$; A negative situation, at maximum risk, arises if this ratio is equal to $70 \%$. The value of the risk-return ratio should not exceed $100 \%(1.00)$.

2.3.1. As a research object, recreational-developed areas have been selected, in which the consolidated frequent tourism makes up more than $60 \%$ in the total volume of management. Natural resources are actively involved here, and balanced conservation is being promoted in order to maintain their conservation. Tourist resources are natural, historical, social and cultural objects that are aimed at satisfying the needs of consumers in providing the relevant service [Валимаки, Тиссари, 1977, 234].

Based on statistical data on the availability of certain resources in recreational-developed territories, a criteristic basis for conducting risk assessment has been identified (Table 1).

Table 1 - Criterion basis for risk assessment with a balanced nature management in recreational-developed territories

\begin{tabular}{|c|c|c|c|}
\hline $\begin{array}{l}\text { Type } \\
\text { of risk }\end{array}$ & Resources & Balance factors & $\begin{array}{c}\text { Criteria for risk } \\
\text { assessment }\end{array}$ \\
\hline 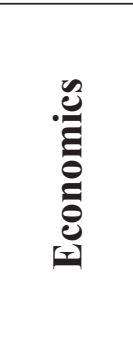 & \multirow{3}{*}{$\begin{array}{l}\text { - } \text { natural (water, } \\
\text { geological, geo- } \\
\text { morphologic, } \\
\text { biological, etc.); } \\
\text { - historical } \\
\text { (sights, } \\
\text { fortresses, } \\
\text { castles, etc.); } \\
\text { - socio-cultural } \\
\text { (museums, } \\
\text { theaters, } \\
\text { galleries, } \\
\text { entertaining } \\
\text { establishments, } \\
\text { architectural } \\
\text { buildings, etc.) }\end{array}$} & $\begin{array}{l}\text { reproduction of natural resources, } \\
\text { preventive measures for the protec- } \\
\text { tion of the environment, control over } \\
\text { the activities of enterprises, waste } \\
\text { treatment and installation of treatment } \\
\text { plants, introduction of innovative } \\
\text { operational requirements }\end{array}$ & \multirow{3}{*}{$\begin{array}{l}\text { - number of objects; } \\
\text { number of objects to be } \\
\text { reconstructed / restored } \\
\text { - availability renewable } \\
\text { natural resources } \\
\text { - the collection and triage } \\
\text { of garbage; } \\
\text { - use of alternative } \\
\text { energy sources; } \\
\text { - level of service } \\
\text { provision (quality, } \\
\text { variety); } \\
\text { - the price for services; } \\
\text { - infrastructure (quality, } \\
\text { variety) }\end{array}$} \\
\hline 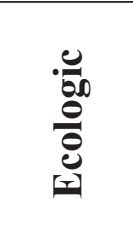 & & $\begin{array}{l}\text { providing environmental and } \mathrm{r} \\
\text { recovery, environmental cl } \\
\text { creating infrastructure for ec } \\
\text { rity, introduction of the re } \\
\text { saving system }\end{array}$ & \\
\hline 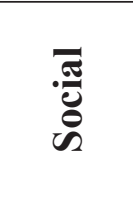 & & $\begin{array}{l}\text { stabilizing the life quality of the popu- } \\
\text { lation, creating conditions for social } \\
\text { security, stimulating the balanced use } \\
\text { of resources }\end{array}$ & \\
\hline
\end{tabular}

Source: compiled by the author with [Балджи, и др., 2013]. 
For further calculations, a quantitative (for parameters that have statistical data) and qualitative (for parameters that are determined subjectively) evaluation was carried out.

An integrated assessment of the risks of sustainable environmental management in the region can be carried out on the basis of an index calculation, which is appropriate to be considered an integral indicator. The values of such an index are estimated on an interval scale of 5 points, on the basis of which it is appropriate to conduct a ranking of territories (Table 2).

Table 2 - Integral scale of risk assessment with balanced nature management in recreationaldeveloped territories

\begin{tabular}{|l|c|l|}
\hline Risk level & Interval Index & \multicolumn{1}{c|}{ Characteristic } \\
\hline $\begin{array}{l}\text { The risk } \\
\text { of an event } \\
\text { occurring }\end{array}$ & $<0,2$ & $\begin{array}{l}\text { violation of natural objects / resources with the possibility of } \\
\text { further restoration; environmental pollution with the possibil- } \\
\text { ity of mechanical cleaning; failure of purification equipment } \\
\text { or alternative energy sources; flooding of roads, landslide etc. }\end{array}$ \\
\hline $\begin{array}{l}\text { Possible } \\
\text { risk }\end{array}$ & $0,2-0,3$ & $\begin{array}{l}\text { violation of natural objects / resources with subsequent resto- } \\
\text { ration with the help of additional funds; environmental pollu- } \\
\text { tion with the possibility of purification; failure of purification } \\
\text { equipment or alternative energy sources, etc.; destruction of } \\
\text { infrastructure; slippery }\end{array}$ \\
\hline $\begin{array}{l}\text { Permissible } \\
\text { risk }\end{array}$ & $0,31-0,49$ & $\begin{array}{l}\text { violation of natural objects / resources with the complexity of } \\
\text { further restoration; environmental pollution with the possibil- } \\
\text { ity of mechanical and chemical purification; malfunction of } \\
\text { treatment equipment, alternative energy sources, etc.; infra- } \\
\text { structure destruction }\end{array}$ \\
\hline $\begin{array}{l}\text { Average } \\
\text { risk level }\end{array}$ & $0,5-0,8$ & $\begin{array}{l}\text { deformation of natural objects / resources with obligatory } \\
\text { restoration, reconstruction; environmental pollution with } \\
\text { complexity, but the possibility of purification; lack of cleaning } \\
\text { equipment and alternative energy sources; Infrastructure is } \\
\text { broken, burevy }\end{array}$ \\
\hline $\begin{array}{l}\text { Maximum } \\
\text { risk }\end{array}$ & $0,81-1,0$ & $\begin{array}{l}\text { destruction of natural objects / resources with difficulty of } \\
\text { restoration to the original state; environmental pollution with } \\
\text { the complexity of purification; malfunction of the treatment } \\
\text { equipment and alternative energy sources that needs to be } \\
\text { replaced; climatic disasters; lack of infrastructure }\end{array}$ \\
\hline
\end{tabular}

The generalized integrated scale of risk assessment with a balanced nature allows to outline the correspondence between the level of risk and the possibility of occurrence of certain events in recreationally developed territories. This will allow not only to identify certain facts and to analyze, but also to make decisions on minimizing risks, management of sustainable development and socio-ecological and economic security.

For recreationally developed territories, which are quite vulnerable to the use of natural resources, the manifestation of high levels of risk leads not only to the lack of recreation, but also to environmental disasters, recovery after which requires significant investment. In such 
conditions, it is necessary to implement measures related to the increased degree of uncertainty and risk, the formation of preventive measures. It was noted above that the risk is considered not only as a negative side, but as a possibility of change. Thus, J. Valimaki and T. Tissari point out that risk is a result of life that needs to be controlled and should be conducted in a well-organized and disciplined style [Валимаки, Тиссари, 1977, 240]. Thus, the manifestation of a risky state can significantly affect the development of a certain recreational and developed area, promote its reconstruction and renewal, but also, respectively, create favorable conditions for holiday recreation and life of local residents. This becomes possible due to the preparation for possible risky situations, the manifestation of crises and disasters, the probability of which is greatly increased due to failure to meet the requirements of balanced nature management. Along with this, there is a need to search for optimal outcomes from a risky state, to form a reserve of material, financial and labor resources, the ability to prepare for critical situations at the lowest cost and be prepared for various problems in advance.

For recreationally developed territories of the Odessa region, the risk level and the availability of resources for recreation and tourism activities are calculated (Fig. 1).

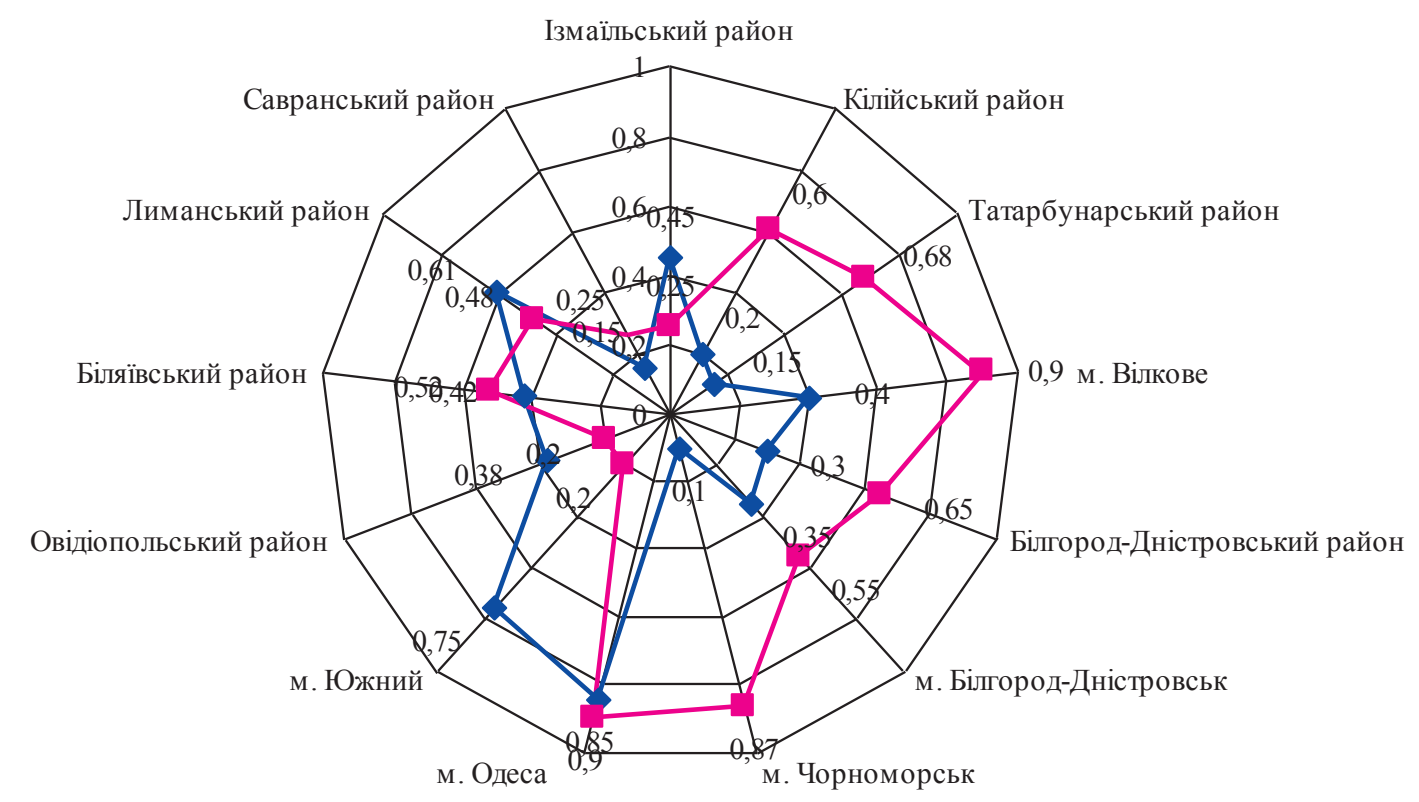

Figure 1. Risk level and the availability of resources for recreation and tourism activities are calculated of the Odessa region

Source: calculated from data $[10,11]$.

The results of the calculations indicate the following pattern: in the presence of a high degree of resource potential, the level of risk increases, which indicates the lack of implementation of the principles of balanced use of nature resources. 
2.3.2. In accordance with the proposed methodological developments, we have carried out a ranking of recreational-developed areas, which is based on the development of a comprehensive risk assessment with a balanced nature management (Fig. 2).

In total, five groups of territories are allocated:

- The first group includes: Savransky and Tatarbunary districts end Chernomorsk city. This is due to the availability of protective resources (afforestation in the Savransky district), coastal strengthening and implementation of resource-saving technologies, sorting and utilization of garbage in the Tatarbunary district and in the city of Chornomorsk. In addition, the last resort has for many years kept a blue flag over the beaches of the city, which indicates the level of purity of the coast, and the presence of new plantations confirms the balance in the use of nature;

- The second group includes the Kiliya district with the availability of intact resources and, consequently, less pollution;

- The third group is the largest and includes: Izmail districts, Vilkovo city, Bilhorod-Dnistrovskyi city, Ovidiopol and Belyaevsky districts. These territories are actively developing in the recreational and tourist direction and have already left the rank of regional facilities for visiting. But the state of natural resources and environmental protection is a better one and needs to be reviewed by the local authorities and territorial communities already established in these areas;

- Group IV includes the Limansky end Bilhorod-Dnistrovskyi districts, which have a fairly extensive network for recreation, infrastructure. Here are the largest beaches of the region, so the maximum pressure from the recreation area falls on these territories, which requires a radical approach to the existing state of nature use;

- V group includes city-ports of the region - Odessa end Yuzhny City, which, along with the existing considerable pressure from tourists, serve as functions of industrial centers and sea gates of the country. Accordingly, significant changes in the field of nature use are required. 


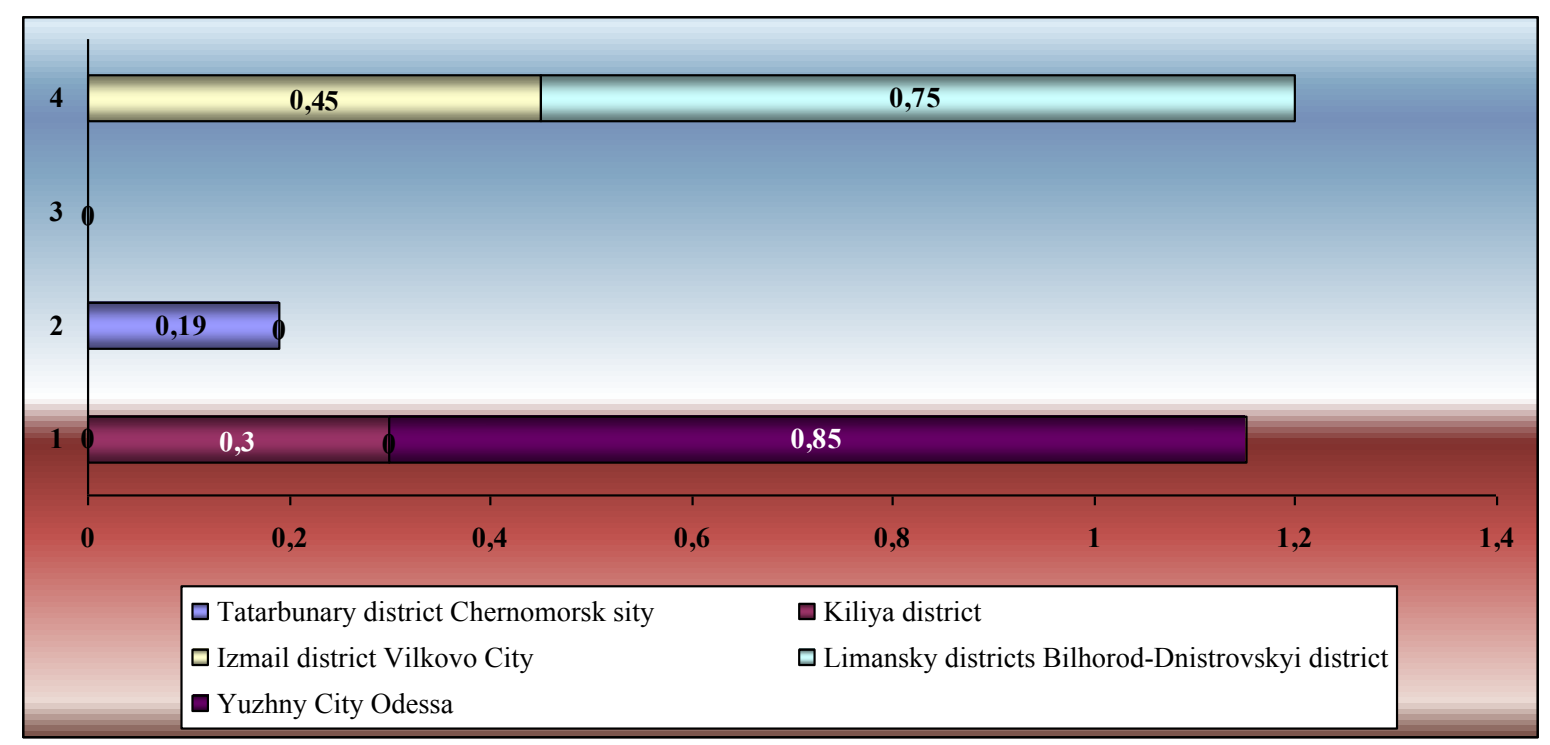

Figure 2. Ranking of recreational-developed territories on the basis of integrated assessment of the risks of balanced use of nature

2.4. Consequently, studies have shown the need to implement the principles of sustainable use of nature. Accordingly, we propose the following recommendations:

- At the present stage of development of the country and its separate territories, the level of threats of the occurrence of risks in the use of nature is rather high, especially in the areas where natural resources are the priority in economic activity. The active use of the last is associated with considerable uncertainty and a large complex of various types of risks, the causes of which may be natural phenomena, as well as anthropogenic actions of direct or indirect nature. Therefore, these causes need to be identified in advance and outlined the preparation for the elimination of risky situations and the manifestation of risks that can be identified by local authorities, entrepreneurs and members of the territorial communities;

- When carrying out a comprehensive environmental risk assessment, it should be noted that any economic activity involving natural resources or the environment is subject to significant risks and threats of natural disasters with severe environmental and economic consequences. In these cases it is better to prevent the process than to stop it. Accordingly, the experience of developed countries in implementing the provisions of sustainable development and the implementation of the principles of balanced use of nature can be actively involved.

\section{Conclusions}

Thus, the definition of risk based on methods of probability theory can be characterized by three factors: an event associated with risk; probability of risks; amount of risk. At the same time, 
analysis and risk assessment are appropriately divided into three categories: direct, inverse and criteria, in further studies and calculations we relied on the last. Quantitative and qualitative methods were used to assess the risk of balanced environmental use, due to the need for decision making, taking into account all possible prerequisites, consequences and probabilities of occurrence of risky events. For the recreationally developed territories of the Odessa region, the risk level and the availability of natural resources have been calculated, which made it possible to rank the selected territories and formulate recommendations for further management, involving principles of balanced nature management and taking into account possible risks.

Relevant studies are appropriate for other recreational-developed areas of the country, which will enable them to distinguish ways of their further development with the introduction of principles of balanced nature management.

\section{Bibliography:}

1. Бернстайн, П. (2000) Против богов: Укрощение риска.

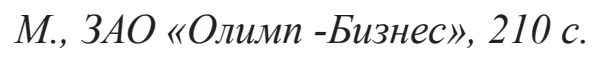

2. Гранатуров, В.М. (1999) Экономический риск: сущуность, методы измерения, пути снижения. М.: Дело и сервис, 1999, 186 с.

3. Ілляшенко, С. М. (2004) Управління екологічними ризиками інновацій. Суми, Університецка книга, 214 с.

4. Клименко, С. М., Дуброва, О. С. (2004) Обгрунтування господарських рімень та оичнка ризику. Київ, КНЕУ, 2004, 272 с.

5. Балджи, М.Д., Карпов, В.А., Ковальов, А.І. та ін. (2013) Обтрунтування господарських рімень і оцінка ризиків. Одеса, Атлант, 670 с.

6. Прокопенко, О.В., Школа, В.Ю., Щербаченко, В.О. та ін. (2017) Управління інноваційною складовою економічної безпеки. Суми, Тристорія, T. IV, 408 с.

7. Туниця, Т.Ю. (2006) Збалансоване природокористування: національний міжнародний контекст. Київ, Знання, 300 с.

8. Захарчук, С.С. (2010) Фінансово-економічні проблеми функціонування туристичної галузі в Україні. Економіка. Управління. Інновації. 1(3). [Електронний ресурс]. Режим доступу: http://www.nbuv.gov.ua/e-journals/eui/2010_1/10zsstgu.pdf.

9. Валимаки, Дж., Тиссари Т. (1977) Управление рисками в инициативах с реинжиниринга бизнеса. Управление рисками в проектах. Симпозиум ИРМА по управлению проектами. Хельсики (Финляндия), с. 233-242.

10. Головне управління статистики в Одеській області [Електронний ресурс]. - Режим доступу: http://www.od.ukrstat.gov.ua/

11. Одеська обласна державна адміністращія. Офімійний сайт. [Електронний ресурс]. Режим доступу: https://oda.odessa.gov.ua/ 